\title{
CrimRxiv
}

\section{Self-Control and Crime: Beyond Gottfredson \& Hirschi's Theory}

\section{Callie Burt}

Published on: Jul 08, 2021

DOI: $10.21428 / \mathrm{cb} 6 a b 371.0281 \mathrm{e} 740$

License: Creative Commons Attribution 4.0 International License (CC-BY 4.0). 
